\title{
Beden Eğitimi ve Spor Öğretmenliğgi Öğrencilerinin Akademik Öz-Düzenlemelerinin İncelenmesi
}

\author{
Investigation of Academic Self-Regulations of Students in Physical Education \\ and Sports Teacher Education
}

\author{
Esin KAPLAN* \\ Zehra CERTEL ${ }^{* *}$
}

$\ddot{O}_{z:}$ Eğitimin önemli hedeflerinden biri, öğrenmenin sorumluluğunu üstlenen, öğrenme süreçlerini kontrol edebilen ve bu öğrenme süreçlerine aktif olarak katılan bireyler yetiştirmektir. Bu hedefe ulaşmada özdüzenleme önemli bir yere sahiptir. Bu araştırmanın amacı Beden Eğitimi ve Spor Öğretmen Adaylarının Öz-düzenleme süreçlerini cinsiyet, düzenli spor yapma, teorik ve uygulamalı ders başarı algılarına göre incelemektir. Araştırma tarama modelindedir. Araştırma, Akdeniz $(\mathrm{n}=110)$, Erciyes $(\mathrm{n}=127)$, Selçuk $(\mathrm{n}=152)$ ve Mehmet Akif Ersoy ( $\mathrm{n}=95)$ Üniversitelerinin Beden Eğitimi ve Spor Öğretmenliği bölümünde öğrenim gören yaş ortalaması ( $\overline{\mathrm{x}}_{\mathrm{yaş}}=21.77 \pm 2.40$ ) yıl olan toplam 484 öğrenci üzerinde gerçekleştirilmiştir. Araştırmada veriler, Martinez-Pons (2000) tarafindan geliştirilen ve Kaplan (2014) tarafindan Türkçeye uyarlanan "Akademik öz-düzenleme ölçeği" ile toplanmıştır. Veriler normal dağılım gösterdiği için ikili karşılaştırmalarda t-testi kullanılmıştır. Sonuç olarak; beden eğitimi ve spor öğretmenliği bölümü öğrencilerinin öz-düzenleme becerileri incelendiğinde kadın öğrencilerin erkek öğrencilere göre anlamlı düzeyde yüksek bulunmuştur. Düzenli spor yapan, teorik ve uygulama ders başarı algısı yüksek olan ögrencilerin öz-düzenleme puanları spor yapmayan, teorik ve uygulamalı ders başarı algısı düşük olan öğrencilere göre istatistiksel olarak anlamlı düzeyde yüksek bulunmuştur.

Anahtar sözcükler: Akademik Öz- Düzenleme, Beden Eğitimi ve Spor, Öğretmen Adayı

Abstract: One of the most important goals of education is to train individuals who are responsible for their own abilities by controlling their own learning processes. Self-control has an important place in reaching this goal. The objective of this study is to examine the Self-regulation processes of Candidates of Physical Education and Sport Teacher on the basis of gender, perceived academic success and regular sport making habits. The study has been executed on a total of 484 students with a mean age $(\bar{X}$ ${ }_{a g e}=21.77 \pm 2.40$ ) year, studying in Akdeniz, Erciyes, Selçuk and Mehmet Akif Ersoy Universities Physical Education and Sport teaching. The data were collected by the "Academic self-regulatory scale" developed by Martinez-Pons (2000) and adapted to Turkish by Kaplan (2014). Since the data show normal distribution, t-test is used in binary comparisons. The self-regulation skills of the students in the physical education and sport teaching department were found to be significantly higher in famele students than the male. Self-regulation scores of students with regular sports and high theoretical and practical achievement perception were found to be statistically significantly higher than those who did not do sports, had a low theoretical and practical achievement perception of course achievement. The self-regulation of women, regular sportsmen and students who perceive themselves as successful in the theoretical courses are high

Keywords: Academic Self-Regulation, Physical Education and Sport, Candidates of Teacher

* Öğr. Gör., Yozgat Bozok Üni., Beden Eği. ve Spor YO., Antrenörlük Eğitimi Böl., Yozgat. esin.kaplan@bozok.edu.tr

** Dr. Öğr. Üyesi, Akdeniz Üni., Spor Bilimleri Fakültesi, Beden Eğitimi ve Spor Eğitimi Böl., Antalya. zcertel@akdeniz.edu.tr 


\section{Giriş}

Bilginin her alanda hızla yenilenerek üretildiği günümüzde öğrencilere kendi öğrenmelerini düzenleme becerileri kazandırmak eğitimin en önemli amaçlarından biri olarak görülmektedir. Öğrenmenin sorumluluğunu üstlenen, kendi öğrenme süreçlerini kontrol edip bu süreçlere aktif olarak katılan ve yeteneklerini olumlu bir şekilde kullanan bireyler yetiştirme de öz-düzenleme önemli bir yere sahiptir (Kaya 2012, Gömleksiz \& Demiralp 2012).

Bandura ve Wood (1989) öz-düzenlemeye sosyal biliş kuramı çerçevesinden yaklaşmıştır. "bireylerin kendi düşünceleri ve hareketleri üzerinde kontrol kurabildikleri içsel bir sisteme sahip olduklarını" belirtmektedir. Bu yaklaşıma göre öz-düzenleme bireylerin içsel yapılarının bir parçasıdır. Zimmerman (2000) ise öğrenme süreci açısından öz-düzenlemeyi tanımlamıştır. Bir anlamda öz-düzenleme, "bireyin kendi ögrenme sürecinin sorumluluğunu alması ve onu aktif olarak kontrol etmesidir". Bu tanım öz-düzenlemenin bireyin aktif katılımını gerektirdiğini ifade eder. Schunk (2001), öz-düzenlemeyi etkileyen en önemli faktörün hedef belirleme olduğunu belirtmektedir. Ona göre hedef belirleme öz-düzenlemenin bir parçasıdır. Hedeflerin belirlenmesi çeşitli alanlarda uygulanabilen genel bir stratejidir. Etkili hedef belirlemede; uzun süreli hedef belirleme, ulaşılabilir alt hedefler, ilerlemeyi izlemek ve yeteneklerini değerlendirmek, strateji ayarlamak ve var olan elde edildiğinde yeni hedefler belirleyen bireyler gerekir. Bu çok aşamalı plan sağl1klı insan fonksiyonunun, yüksek motivasyon ve algılanan öz-yeterliliğin, öz-düzenlemeli öğrenme ve ömür boyunca performansın bir anahtarıdır. Etkili öz-düzenleme becerilerine sahip bireyler ulaşlabilir hedefler belirleyerek ilerlemelerini bu hedefler doğrultusunda gözlemlerler ve belirledikleri hedefler doğrultusundaki ilerlemenin yetersiz olduğu durumlarda ise yeni stratejiler kullanırlar.

Bandura ve Wood (1989) öz-düzenlemeye sosyal biliş kuramı çerçevesinden yaklaşmış ve bireylerin kendi düşünceleri ve hareketleri üzerinde kontrol kurabildikleri içsel bir sisteme sahip olduklarını belirtmektedir. Son yıllarda öz-düzenlemeye dayalı öğrenme kavramı, eğitim uygulamalarının ve araştırmalarının odak noktasını oluşturmuştur. Bunun temel sebebini, Tanrıseven ve Dilmaç (2013), öz-düzenlemeye dayalı olan öğrenmenin, öğrencinin akademik performansı ve başarısı üzerinde etkili bir değişken olmasından kaynaklandığını belirtmişlerdir.

Eğitim ortamında öz-düzenleme becerisine sahip olan öğrenciler bilgi ve beceri elde etmede öğretmen, aile ya da diğer unsurlara güvenmekten çok kendi öğrenme süreçlerini yönetmede daha iyidirler. Bu şekilde öz-düzenlemeli öğrenme ortamları oluşturmak, öz-düzenlemeye sahip olan bireyler yetiştirebilmek için önemlidir. Öz-düzenlemeli öğrenme; anlama ve öğrenmeyi kontrol edebilme yeteneği olarak tanımlanabilir.

Yapılan literatür taramasında, yurtiçinde öz-düzenleme üzerinde yapılan çalışmalarda araştırmacılar daha çok, öz-düzenleme ve öğrenme ilişkisi, öz-düzenleme becerilerinin etkin bir şekilde kullanılması, öz-düzenleme öğretiminin önemi ve akademik başarı ile ilişkisini incelemişlerdir (Üredi 2005; Canca 2005; Arsal 2009; Arslan 2011; Uygun 2012). Ayrıca öğrencilerin bir ders üzerinde (genellikle Matematik ve Fen dersleri) gösterdiği öz-düzenleme beceri ve strateji kullanımına ilişkin çalışmalara yer verilmiştir (Üredi \& Üredi 2005; İsrael 2007; Alıcı \& Altun 2007).

Yurtdışında yapılan çalışmalarda ise etkili öz-düzenleme yapabilen bireylerin özellikleri, özdüzenleme süreçleri ve bu süreçlerin kendi aralarındaki etkileşimlerine odaklanılmıştır. Öz-düzenleme yapan bireylerin kullandıkları stratejiler ve bu stratejilerin kazandırılması, öz-düzenlemenin başarı, değerler, amaç yönelimleri, yüklemeler gibi eğitimsel kavramlarla ilişkilerini belirlemeye çalışmışlardır. Ayrıca, öz-düzenlemenin gelişimi ve öz-düzenleme eğitimi konularını da ele almışlardır (Zimmerman \& Pons 1995; Azevedo et al. 2005; Olson 2009; Toering et al. 2012). 
Yaşam boyu öğrenmede önemli rol oynayan öz-düzenlemenin beden eğitimi ve spor alanında gerçekleştirilmesinde en önemli rol oynayan öğretmenlerin öz-düzenlemeye sahip olmaları beklenmektedir. Beden eğitimi ve spor öğretmen adaylarının öz-düzenleme seviyelerinin belirlenmesi ve öz-düzenlemeyi belirleyici nedenlerin bilinmesi öğrenmeyi üst düzeye çıkarmak için gerekli olan fikri verebilir. Öğretmen adaylarıyla ile ilgili olarak, devam eden araştırmalar gelecekte eğitimciler için üniversite eğitim programlarının değişmesine ve gelişmesine katkı sağlayabilir. Öğrencilerin kişisel hedeflerine ulaşma yeteneğinin artması, kişinin kendi özdüzenlemesini yapabilmesi ve çalışma alanında da pozitif olarak bilişsel yeteneklerini gösterilmesine olanak sağlayarak yaşam boyu devam etmesini mümkün kılabilir.

Bu bilgiler 1şığında Türkiye'de beden eğitimi ve spor öğretmen adaylarının öz-düzenlemelerinin araştırıldığ 1 bir çalışmaya rastlanmaması bu alanda yapılan çalışmalara ihtiyaç duyulduğunun bir göstergesidir. Bu bağlamda araştırmanın amacı, beden eğitimi ve spor öğretmen adaylarının öz-düzenleme süreçlerini cinsiyet, düzenli spor yapma durumlarına ve algılanan teorik ve uygulamalı ders başarısına göre incelemektir.

\section{Yöntem}

\section{Araştırmanın Modeli}

Araştırma, tarama modelindedir. Tarama araştırmaları, bir grubun bazı özelliklerini belirlemek için verilerin toplanmasını amaçlayan çalışmalar olarak ifade edilmektedir (Büyüköztürk 2011).

\section{Çalışma Grubu}

Araştırmanın evrenini, Türkiye'deki Beden Eğitimi ve Spor Yüksekokulu (2013-2014 öğretim y1lı) Beden Eğitimi ve Spor Öğretmenliği bölümü birinci, ikinci, üçüncü ve dördüncü sinıflarında öğrenimine devam eden öğrenciler oluşturmaktadır. Araştırma Akdeniz ( $\mathrm{n}=110)$, Erciyes $(\mathrm{n}=127)$, Selçuk $(\mathrm{n}=152)$ ve Mehmet Akif Ersoy $(\mathrm{n}=95)$ Üniversitelerinin Beden Eğitimi ve Spor Öğretmenliği bölümünde öğrenim gören yaş ortalamas $\left(\bar{X}_{\text {yaş }}=21.77 \pm 2.40\right)$ yıl olan toplam 484 öğrenci üzerinde gerçekleştirilmiştir. Üniversitelerin Beden Eğitimi ve Spor Öğretmenliği 1. 2. 3. ve 4.sınıf öğrencilerine uygulama yapılabilmesi için gerekli izinler alınmıştır. Veriler adı geçen üniversitelerde görev yapan bir öğretim elemanı tarafindan toplanmıştır. Uygulama öncesinde öğrencilere araştırmanın amacı açılanmış ve ölçme aracı tanıtılmıştır. Sonrasında ise öğrencilerden öncelikle her boyutun yönergesini okuyarak sorulara cevap vermeleri istenmiştir. Araştırmada ölçeğin uygulandığ gün okulda bulunan gönüllü öğrenciler örneklemi oluşturmuştur.

Araştırmada uygun örnekleme modeli kullanılmıştır. Uygun örnekleme modelinde araştırmacı, örneklemini oluşturmaya en ulaşılabilir olan yanıtlayıcılardan başlamak üzere başlar ya da bazı sınırlılıklar nedeniyle (zaman, para ve işgücü gibi) örneklemin kolay ulaşılabilir birimlerden seçilmesidir (Büyüköztürk 2011). Örnekleme ilişkin betimsel istatistikler Tablo 1.'de verilmiştir.

Tablo 1. Örneklemde Yer Alan Üniversite Öğrencilerinin Betimsel İstatistikleri

\begin{tabular}{llcc}
\hline Değişkenler & & $\mathbf{n}$ & $\mathbf{\%}$ \\
\hline Cinsiyet & Kadın & 224 & 46.3 \\
& Erkek & 260 & 53.7 \\
\hline Düzenli Spor Yapma & Yapmıyorum & 179 & 37.0 \\
Durumu & Yapıyorum & 305 & 63.0 \\
\hline Algılanan Teorik Ders & Başarılı & 186 & 38.4 \\
Başarısı & Orta düzey & 298 & 61.6 \\
\hline Algılanan Uygulamalı Ders & Başarılı & 325 & 67.1 \\
Başarısı & Orta düzey & 159 & 32.8 \\
\hline
\end{tabular}


Tablo 1 incelendiğinde, öğrencilerin 224 (\%46.3)'ü kadın, 259 (\%53.7)'u erkektir. Öğrencilerin $179(\% 37.0)$ 'u, düzenli spor yapmamakta, $305(\% 63.0)$ ' $i$ ise düzenli spor yapmaktadır. Öğrencilerin 186 (\%38.4)'sının teorik ders başarı algısı başarılı, 298 (\%61.6)'inin ise teorik ders başarı algısı orta düzeydedir. Uygulama ders başarısı algısı ise 325 (67.1)'nin başarıl1, 152 (\%31.4)'sinin ise orta düzeydedir.

\section{Veri toplama araçları}

Araştırmada veriler "Akademik Öz-düzenleme Ölçeği (AÖÖ)" ve kişisel bilgi formu ile toplanmiştır.

Akademik Öz-düzenleme Ölçeği (AöÖ): Araştırmada veri toplama aracı olarak Manuel Martinez-Pons (2000) tarafından geliştirilen ve Kaplan (2014) tarafından Türkçe'ye uyarlanan "Akademik Öz-düzenleme Ölçeği (AÖÖ)" kullanılmıştır. Bu ölçek öz-düzenlemenin sosyal bilişsel yapısına dayanarak lisans öğrencilerinin öz-düzenleme yeteneklerini değerlendirmek için geliştirilmiştir. Öncelikle 48 maddelik ölçeğe yanıt vermiş 484 kişilik örneklemden elde edilen verilerin faktör analizine uygunluğu Kaiser-Meyer-Olkin (KMO) ve Barlett testi ile sınanmıştır. KMO değeri .954 ve Barlett testi ile elde edilen Ki-Kare değeri $\left(\chi^{2}=16553.519\right.$, $\mathrm{sd}=1176, \mathrm{p}=.000$ ), anlamlı bulunmuştur. Açımlayıcı faktör analizi sonucunda öz değeri 1.00 'den yüksek olan ve varyansın \%55.453'ni açıklayan dört faktörlü çözüme ulaşılmıştır. Doğrulayıcı faktör analizi ile sınanan modelin uyum indeksleri değerleri ise, RMSEA 0.080, $\mathrm{RMR}=0.15, \mathrm{SRMR} 0.056, \mathrm{GFI}=0.72, \mathrm{AGFI}=0.70, \mathrm{CFI}=0.97, \mathrm{NNFI}=0.96$ ve $\mathrm{NFI}=0.95$ olarak bulunmuştur.48 madde olan ölçek hedef belirleme (15 madde), strateji uygulama (14 madde), strateji izleme (15 madde), ve destek alma (4 madde) olmak üzere dört alt boyuta sahiptir. Ölçek 7'li likert tipindedir. Bu araştırmada ölçeğin güvenirlik katsayıları "hedef belirleme" alt boyutu Cronbach alfa iç tutarl111k katsayısı $\alpha=.93$, "strateji uygulama" $\alpha=.93$, "strateji izleme" $\alpha=.95$, "destek alma" $\alpha=.88$ ve ölçeğin toplamı için ise $\alpha=.97$ olarak bulunmuştur.

Kişisel Bilgi Formu: Öğrencilerin algılanan hem teorik ve hem de uygulamalı ders başarı algılarını, kişisel bilgi formunda yer alan "Akademik başarı açısından kendinizi nasıl değerlendiriyorsunuz?" sorusuna başarıl1, orta düzey veya başarısız seçeneklerinden birine yanıt vererek değerlendirmeleri istenmiştir. Ancak teorik ve uygulamalı derslerde kendini başarısız olarak değerlendiren üç kişi olduğundan başarı algısı, başarılı ve orta düzey olarak alınmıştır. Öğrencilerin düzenli spor yapıyor olarak kabul edilmesi için en az bir yıl boyunca haftada üç gün düzenli olarak egzersiz veya spor yapmaları gerekmektedir.

\section{Veri analizi}

Araştırmadan elde edilen verilerin istatistiksel çözümlemeleri SPSS 18.00 paket programı kullanılarak yapılmıştır. Araştırmada verilerin analizinde kişisel bilgiler için betimsel istatistik yöntemleri olan frekans (n), yüzde (\%), aritmetik ortalama $(\overline{\mathrm{X}})$ ve standart sapma (Ss) kullanılmıştır. Araştırmada verilerin dağılımı incelemek için Kolmogorow Smirnow testi yapılmıştır. Veriler normal dağılım gösterdiği için ikili karşılaştırmalarda t-testi kullanılmıştır ve anlamlılık düzeyi .05 olarak alınmıştır.

\section{Bulgular}

$\mathrm{Bu}$ bölümde, çalışmadan elde edilen verilerin analizi sonucunda elde edilen beden eğitimi ve spor öğretmen adaylarının cinsiyet, düzenli spor yapma ve algılanan toerik ve uygulamalı ders başarı değişkenlerine göre öz-düzenleme durumları bulguları yer almaktadır. Öğrencilerin akademik öz-düzenleme puan ortalamalarının cinsiyete göre t-testi sonuçları Tablo 2 'de verilmiştir. 
Tablo 2. .Öğrencilerin Akademik Öz-Düzenleme Puan Ortalamalarının Cinsiyete Göre t-testi Sonuçları

\begin{tabular}{ccccccc}
\hline Ölçek & Cinsiyet & $\mathbf{n}$ & $\overline{\mathrm{X}}$ & $\mathbf{S s}$ & $\mathbf{t}$ & $\mathbf{p}$ \\
\hline \multirow{2}{*}{ Hedef belirleme } & Kadın & 224 & 4.92 & 1.03 & & \\
& Erkek & 260 & 4.75 & 1.07 & 1.747 & .081 \\
\hline \multirow{2}{*}{ Strateji } & Kadın & 224 & 4.71 & 1.14 & & \\
uygulama & Erkek & 260 & 4.30 & 1.13 & $3.992^{*}$ & .000 \\
\hline \multirow{2}{*}{ Strateji izleme } & Kadın & 224 & 4.73 & 1.13 & & \\
& Erkek & 260 & 4.37 & 1.19 & $3.336^{*}$ & .001 \\
\hline \multirow{2}{*}{ Destek alma } & Kadın & 224 & 4.43 & 1.31 & & \\
& Erkek & 260 & 4.07 & 1.25 & $3.137^{*}$ & .002 \\
\hline \multirow{2}{*}{ Ölçek toplam } & Kadın & 224 & 4.70 & .98 & & \\
& Erkek & 260 & 4.37 & .94 & $3.727^{*}$ & .000 \\
\hline $\mathbf{p}<0.05$ & & & & & &
\end{tabular}

Tablo 2 incelendiğinde, öğrencilerin cinsiyetlerine göre hedef belirleme $(t=1.747, p=.081$; $\mathrm{p}>05$ ) puan ortalamaları arasında istatistiksel olarak anlamlı bir farklılık bulunmamıştır. Buna karşın strateji uygulama $(\mathrm{t}=3.992, \mathrm{p}=.000, \mathrm{p}<05)$, strateji izleme $(\mathrm{t}=3.336 \mathrm{p}=.001, \mathrm{p}<05)$, destek alma $(t=3.137, p=.002, p<05)$ ve akademik öz-düzenleme ölçeği toplamı $(t=3.727$, $\mathrm{p}=.000, \mathrm{p}<05)$ puan ortalamaları arasında istatistiksel olarak anlamlı farklılıklar bulunmuştur. Kadın öğrencilerin alt boyutlarda ve ölçek toplamında puan ortalamaları erkek öğrencilere göre yüksektir. Öğrencilerin akademik öz-düzenleme puan ortalamalarının düzenli spor yapma durumuna göre t-testi sonuçları Tablo 3'de verilmiştir.

Tablo 3. .Öğrencilerin Akademik Öz-Düzenleme Puan Ortalamalarının Düzenli Spor Yapma Durumuna Göre t-testi Sonuçları

\begin{tabular}{|c|c|c|c|c|c|c|}
\hline Ölçek & $\begin{array}{c}\text { Düzenli Spor } \\
\text { Yapma }\end{array}$ & $\mathbf{n}$ & $\bar{X}$ & Ss & $\mathbf{t}$ & $\mathbf{p}$ \\
\hline Hedef belirleme & $\begin{array}{l}\text { Yapmiyorum } \\
\text { Yapiyorum }\end{array}$ & $\begin{array}{l}179 \\
305\end{array}$ & $\begin{array}{l}4.70 \\
4.91\end{array}$ & $\begin{array}{l}1.06 \\
1.05\end{array}$ & $-2.054^{*}$ & .041 \\
\hline Strateji uygulama & $\begin{array}{l}\text { Yapmiyorum } \\
\text { Yapiyorum }\end{array}$ & $\begin{array}{l}179 \\
305 \\
\end{array}$ & $\begin{array}{l}4.36 \\
4.57 \\
\end{array}$ & $\begin{array}{l}1.09 \\
1.18 \\
\end{array}$ & $-1.980 *$ & .048 \\
\hline Strateji izleme & $\begin{array}{l}\text { Yapmiyorum } \\
\text { Yapiyorum }\end{array}$ & $\begin{array}{l}179 \\
305\end{array}$ & $\begin{array}{l}4.36 \\
4.64\end{array}$ & $\begin{array}{l}1.13 \\
1.19\end{array}$ & $-2.496^{*}$ & .013 \\
\hline Destek alma & $\begin{array}{l}\text { Yapmiyorum } \\
\text { Yapiyorum }\end{array}$ & $\begin{array}{l}179 \\
305\end{array}$ & $\begin{array}{l}4.05 \\
4.35\end{array}$ & $\begin{array}{l}1.36 \\
1.24\end{array}$ & $-2.440^{*}$ & .015 \\
\hline Ölçek toplam & $\begin{array}{l}\text { Yapmiyorum } \\
\text { Yapiyorum }\end{array}$ & $\begin{array}{l}179 \\
305\end{array}$ & $\begin{array}{l}4.37 \\
4.61\end{array}$ & $\begin{array}{l}.95 \\
.97\end{array}$ & $-2.721^{*}$ & .007 \\
\hline
\end{tabular}

Tablo 3 incelendiğinde, öğrencilerin düzenli spor yapma durumlarına göre; hedef belirleme ( $\mathrm{t}=$ 2.054, $\mathrm{p}=.041, \mathrm{p}<05)$, strateji uygulama $(\mathrm{t}=-1.980 \mathrm{p}=.048, \mathrm{p}<05)$, strateji izleme $(\mathrm{t}=-2.496$, $\mathrm{p}=.013, \mathrm{p}<05)$, destek alma $(\mathrm{t}=-2.440, \mathrm{p}=.015, \mathrm{p}<05)$ ve akademik öz-düzenleme ölçeği toplamı $(\mathrm{t}=-2.721, \mathrm{p}=.007, \mathrm{p}<05)$ puan ortalamaları arasında düzenli spor yapan öğrencilerin lehine istatistiksel açıdan anlamlı farklılıklar bulunmuştur. Akademik öz-düzenleme ve toplam puanlarının teorik ders başarı algısına göre farklılık gösterip göstermediği t-testi ile sınanmıştır. Tablo 4'de ögrrencilerin akademik öz-düzenleme puan ortalamalarının algılanan teorik ders başarısına göre dağılım sonuçları verilmiştir. 
Tablo 4. Öğrencilerin Akademik Öz-Düzenleme Puan Ortalamalarının Algılanan Teorik Ders Başarısına Göre Dağılımına İlişkin t-testi Sonuçları

\begin{tabular}{cccccc}
\hline Ölçek & Teorik ders başarısı & $\mathbf{n}$ & $\overline{\mathbf{X}}$ & $\mathbf{t}$ & $\mathbf{p}$ \\
\hline $\begin{array}{c}\text { Hedef } \\
\text { belirleme }\end{array}$ & Başarılı & 186 & 5.13 & & \\
\hline Strateji & Orta düzey & 298 & 4.64 & $5.146^{*}$ & .000 \\
\hline uygulama & Başarılı & 186 & 4.91 & & \\
\multirow{2}{*}{ Strateji izleme } & Orta düzey & 298 & 4.23 & $6.571^{*}$ & .000 \\
\hline \multirow{2}{*}{ Destek alma } & Başarılı & 186 & 4.92 & & \\
& Orta düzey & 298 & 4.29 & $5.919^{*}$ & .000 \\
\hline \multirow{2}{*}{ Ölçek toplam } & Başarılı & 186 & 4.44 & & \\
& Orta düzey & 298 & 4.29 & $2.792^{*}$ & .005 \\
\hline *p $<.05$ & Başarılı & 186 & 4.85 & & \\
& Orta düzey & 298 & 4.32 & $6.112^{*}$ & .000 \\
\hline
\end{tabular}

Tablo 4 incelendiğinde öğrencilerin teorik ders başarı düzeyi düştükçe öz-düzenleme puan ortalamalarının da düştüğü gözlenmektedir. Kendisini teorik derslerde başarılı, orta düzey algılayan öğrencilerin hedef belirleme $(\mathbf{t}=5.146, \mathrm{p}=.000, \mathrm{p}<05)$, strateji uygulama $(\mathbf{t}=6.571$, $\mathrm{p}=.000, \mathrm{p}<05)$, strateji izleme $(\mathrm{t}=5.919, \mathrm{p}=.000, \mathrm{p}<05)$, destek alma $(\mathrm{t}=2.792, \mathrm{p}=.005, \mathrm{p}<05)$ ve AÖÖ ölçeği toplamı $(\mathbf{t}=6.112, \mathrm{p}=.000, \mathrm{p}<05)$ puan ortalamaları arasında istatistiksel açıdan anlamlı farklılıklar bulunmuştur. Tablo 5 'de öğrencilerin Akademik öz-düzenleme puan ortalamalarının algılanan uygulamalı ders başarısına göre dağılımına ilişkin t-testi sonuçları verilmiştir.

Tablo 5. Öğrencilerin Akademik Öz-Düzenleme Puan Ortalamalarının Algılanan Uygulamalı Ders Başarısına Göre Dağılımına İlişkin t-testi Sonuçları

\begin{tabular}{cccccc}
\hline Ölçek & Uygulamalı ders başarısı & $\mathbf{n}$ & $\overline{\mathrm{X}}$ & $\mathbf{t}$ & $\mathbf{p}$ \\
\hline \multirow{2}{*}{ Hedef belirleme } & Başarılı & 325 & 4.92 & & \\
& Orta düzey & 159 & 4.65 & $2.642^{*}$ & .009 \\
\hline \multirow{2}{*}{ Strateji } & Başarılı & 325 & 4.60 & & \\
uygulama & Orta düzey & 159 & 4.26 & $3.119^{*}$ & .002 \\
\hline \multirow{2}{*}{ Strateji izleme } & Başarılı & 325 & 4.65 & & \\
& Orta düzey & 159 & 4.29 & $3.200^{*}$ & .001 \\
\hline \multirow{2}{*}{ Destek alma } & Başarı̈ı & 325 & 4.24 & & \\
& Orta düzey & 159 & 4.24 & .002 & .998 \\
\hline \multirow{2}{*}{ Ölçek toplam } & Başarılı & 325 & 4.60 & & \\
& Orta düzey & 159 & 4.36 & $2.610^{*}$ & .009 \\
\hline
\end{tabular}

$* \mathrm{p}<0.05$

Tablo 5 incelendiğinde öğrencilerin uygulamalı ders başarı düzeyi düştükçe öz-düzenleme puanlarının da düştüğü gözlenmektedir. Kendisini uygulamalı derslerde başarılı ve orta düzey algilayan öğrencilerin hedef belirleme $(\mathbf{t}=2.642, \mathrm{p}=.009, \mathrm{p}<05)$, strateji uygulama $(\mathbf{t}=3.119$, $\mathrm{p}=.002 ; \mathrm{p}<05)$, strateji izleme $(\mathbf{t}=3.200, \mathrm{p}=.001, \mathrm{p}<05)$ ve AÖÖ ölçeği toplamı $(\mathbf{t}=2.610$, $\mathrm{p}=.009, \mathrm{p}<05)$ puan ortalamaları arasında istatistiksel açıdan anlamlı farklılıklar bulunmuştur $(\mathrm{p}<.001)$. Destek alma alt boyutunda ise istatistiksel açıdan anlamlı bir fark bulunmamıştır $(\mathbf{t}=.002, \mathrm{p}=998 ; \mathrm{p}>.05)$. 


\section{Tartışma}

Beden eğitimi ve spor öğretmenliği öğrencilerinin, öz düzenleme becerilerini cinsiyet, teorik ve uygulama ders başarı algıları ve düzenli spor yapma durumlarına göre incelemek amacıyla yapilan araştırmada aşağıdaki sonuçlara ulaşılmıştır.

$\mathrm{Bu}$ araştırmada cinsiyetin hedef belirleme alt boyutu dışında öz-düzenlemeyi etkilediği ortaya çıkmıştır. Kadın öğrencilerin strateji uygulama, strateji izleme, destek alma ve AÖÖ toplamında, erkeklere göre daha fazla öz-düzenleme becerilerine sahip oldukları bulunmuştur. Hedef belirleme boyutunda ise kadın ve erkek öğrenciler benzerlik göstermektedir. Bu sonuca göre, kadın öğretmen adayların öğrenmelerini gerçekleştirirken erkek öğretmen adaylarına göre mantıklı bir yol izlediklerini, öğrenmelerini sürekli olarak kontrol ettiklerini göstermektedir. Ayrıca kadın öğrencilerin öz-düzenlemelerinin yüksek olması, akademik beklentilerin yüksek olması gibi etkilerden de kaynaklanmış olabileceği düşünülmektedir. Alıcı ve Altun (2007) lise öğrencilerinin matematik dersine yönelik öz-düzenleme ve bilişüstü becerilerini inceleyen çalışmasında kız öğrencilerin lehine bulgular bulmuştur. Kurman (2004) araştırmasında, cinsiyetin matematik ve öz düzenleme becerisi için anlamlı bir yordayıcı olduğunu gösterirken, matematik için kızlarda kendini geliştirme çabası ile öz düzenleme becerisi arasında ise pozitif korelasyon olduğunu ortaya koymuştur. Yüksel (2013)'in yaptığı çalışmada da kadın öğretmen adaylarının öz-düzenleme becerilerinin erkek öğretmen adayların öz-düzenleme becerilerine göre daha yüksek düzeyde oldukları belirlenmiştir. Görüldüğü gibi söz konusu çalışmalar bu araştırma bulgularını destekler niteliktedir. Yine Gömleksiz ve Demiralp (2012) ve Schuitema ve ark. (2012) da yaptıkları çalışmalarda cinsiyet faktörünün kızlar lehine farklılık oluşturduğunu saptamışlardır. Görüldüğü gibi söz konusu çalışmalar, bu araştırma bulgularını destekler niteliktedir

$\mathrm{Bu}$ çalışmada düzenli spor yapma durumu akademik öz-düzenlemeyi hedef belirleme, strateji uygulama, strateji izleme, destek alma boyutlarında etkilediği ortaya çıkmıştır. Başka bir deyişle düzenli olarak spor yapan öğrencilerin öz-düzenleme becerileri daha yüksek bulunmuştur. Düzenli spor yapan öğrencilerin duygu, düşünce ve davranışlarını belli hedefleri için düzenledikleri, stratejik planlamalar yaptıkları, daha sonra bu planları için stratejilerini uyguladıkları ve kendi içerisinde tekrar öz değerlendirme yaparak kendi davranışlarını, duygularını ve düşüncelerini gözden geçirdikleri ve gerekli öz-düzenlemeyi yaptıkları söylenebilir. Çalışma sonuçları düzenli spor yapmanın öz-düzenleme üzerindeki etkililiğini gözler önüne sermektedir. Yurtiçi literatür taramasında akademik öz-düzenlemeyi beden eğitimi öğretmen adayları üzerinde inceleyen ve spor yapma durumuna göre kıyaslayan çalışmaya rastlanmamıştır. Ancak yurtdışında yapılan çalışmalar incelendiğinde beden eğitimi ve spor öğretmen adayları ile ilgili çalışmalara rastlanmıştır. Ommundsen (2006), araştırmasında motivasyonel iklim ve meta-bilişsel öz-düzenleme için farklı başarı hedefleri, çaba düzenleme, yardım arama ve beden eğitiminde kendi kendini engelleme ilişkilerini incelemiştir. Öz-düzenleme ile hem motivasyonel iklim hem de hedefe ulaşma incelenmiştir. Sonuçlar, performans üzerindeki farklı öz-düzenleme etkilerinin (performansa yaklaşma ve hedeften kaçınma gibi) öğrencilerin özdüzenlemelerinde etkili olduğunu göstermiştir.

Beden eğitimi ve spor öğretmenliği öğrencilerinin akademik öz-düzenleme düzeyleri alg1lanan teorik ders başarı algılarına ve uygulamalı ders başarılarına göre incelenmiş̧tir. Araştırma sonuçlarına göre öğrencilerin teorik ve uygulamalı derslerdeki başarı algılarının akademik özdüzenlemeyi etkilediği ortaya çıkmıştır. Çalışmamızda beden eğitimi ve spor öğretmenliği öğrencilerinin teorik ve uygulamalı derslerdeki başarı algıları yüksek olan öğrencilerin akademik öz-düzenlemelerinin yüksek olduğu, bu öğrencilerin daha fazla öz-düzenleme becerilerini kullandığı görülmüştür. Günümüzde bilginin öğrenciler tarafından aktif olarak alınması ve düzenlenmesi büyük önem taşımaktadır. Bilişini, motivasyonunu kullanan öğrencilerin perfor- 
mans ve akademik başarı yönünden daha iyi sonuçlar aldığ 1 görülmektedir. Akademik başarı algısında görülen bu durum öğrencilerinin belli bir düzeyde öğrenmede öz-düzenleme stratejilerini kullandığını göstermektedir. Literatür incelendiğinde bu çalışmayı destekleyen birçok çalışmaya rastlamak mümkündür. Pintrich ve de Groot (1990) ve Andrew ve Vialle (1998) öz yeterlilik algısı ile birlikte öğrenmede öz-düzenleme stratejileri ve akademik başarı arasındaki ilişkiyi ele almışlardır. Öğrencilerin başarı düzeyleri ile öz-yeterlilik algıları ve öğrenmede öz-düzenleme stratejilerini kullanma düzeyleri arasında anlamlı derecede ilişkiler bulunmuştur. Miller (2000), öğrenmede öz-düzenleme ve başarı arasındaki ilişkiyi, içsel ve dışsal karşılaştırmalar çercevesinde incelemiştir. Araştırma sonucunda öz-düzenleme ve başarı arasında pozitif yönde bir ilişki bulmuştur. Söz konusu araştırma bulguları, araştırmamızı destekler niteliktedir. Yurtiçi literatür taramasında da bu çalışmayı destekleyen verilere ulaşılmıştır. Yüksel (2013), çalışmasında öğretmen adaylarının öz-düzenleme beceri düzeyleri ile başarı düzeyleri arasında pozitif yönde orta düzeyde ilişki olduğunu belirtmiştir. Sonuç olarak; kadın öğrencilerin, düzenli spor yapan öğrencilerin, uygulamalı ve teorik ders başarı algısı yüksek olan öğrencilerin öz-düzenleme becerileri de yüksek bulunmuştur.

\section{Öneriler}

Araştırmadan elde edilen bulgulara göre öğrencinin başarılı olabilmesi için öz-düzenleme becerilerine sahip olmaları gerekmektedir. Öğrenci başarısını yükseltebilmek için, öğrencilerin özdüzenleme becerilerine yönelik kurs-seminer gibi etkinliklere yer verilmesi, projeler ve ödevlerle öğrencilerin yönlendirilmesi öz-düzenleme becerilerinin geliştirilmesine katkı sağlayabilir.

Araştırmada öğrencilerin düzenli spor yapma durumları öz-düzenlemeyi olumlu olarak etkilediği sonucuna ulaşılmıştır. Bilindiği gibi spor, ortaya çıkışından bu yana toplumsal yaşantının önemli bir parçası haline gelmiştir. Serbest zamanın değerlendirilmesi, kendine güveni, sosyalleşmeyi ve dayanışmayı sağlamasının yanında bireyin fiziksel ve ruhsal sağlığının gelişmesindeki rolü yadsınamaz. $\mathrm{Bu}$ bağlamda öğrencilerin sevdikleri bir spor etkinliğine yönlendirilmeleri sağlanarak, bu etkinliği gerçekleştirirken aynı zamanda öz-düzenleme becerileri kazandırılabilir.

Geleneksel eğitimde kullanılan yöntem ve teknikler öğrencilerin öğrenmelerinin sorumluluğunu almalarına, öğretim materyaliyle ve birbirleriyle aktif olarak etkileşmelerini sağlamalarına olanak vermemektedir. Bu nedenle öğrencilerin derse karşı güdüleri, öğrenme istekleri ve ilgileri azalmaktadır. $\mathrm{Bu}$ durum öğrencinin öz-düzenlemesini olumsuz etkilemektedir. $\mathrm{Bu}$ bağlamda derslerde aktif öğrenme yöntemleri kullanıp öğrencileri derslerde aktif hale getirmek başka bir deyişle eğitimlerinin öz-düzenleme becerilerini geliştirmeye yönelik yöntem, teknik ve öğretimsel işlerle desteklenmesi büyük yarar sağlayacaktır.

\section{Yazarın notu}

$\mathrm{Bu}$ araştırma Akdeniz Üniversitesi Sağlık Bilimleri Enstitüsünde yapılan Yüksek Lisans tezinden derlenmiştir. 9. Uluslararası Beden Eğitimi ve Spor Öğretmenliği Kongresinde poster bildiri olarak sunulmuştur. 


\section{KAYNAKÇA}

Alıcı B. \& Altun S. (2007). "Lise Öğrencilerinin Matematik Dersine Yönelik Öz-Düzenleme ve Bilişüstü Becerileri, Cinsiyete, Sınıfa ve Alanlara Göre Farklılaşmakta Mıdır?”. Çukurova Üniversitesi Sosyal Bilimler Enstitüsü Dergisi 16/1 (2007) 33-44.

Andrew S. \& Vialle W. (1998). "Nursing Students' Self-Efficacy, Self-Regulated Learning and Academic Performance in Science Teaching". Paper Presented at the Australian Association for Research in Education Conference (1998).

Arsal Z. (2009). "The Effects of Diaries on Self-Regulation Strategies of Preservice Science Teachers". International Journal of Environmental \& Science Education 5/1 (January, 2009) 85-103.

Arslan A. (2011). "Ayrılıp Birleşme IV Tekniğinin Erişiye, Öz Yeterlik İnancına ve Öz-Düzenleme Becerisine Etkisi”. ZKÜ Sosyal Bilimler Dergisi 7/13 (2011) 369-385.

Aydın S. (2012). Proje Tabanlı Öğrenme Ortamlarının Biyoloji Öğretmen Adaylarının Öz-Düzenleme Seviyeleri ve Öz-Yeterlik Inançları Üzerine Etkisi. Yayımlanmamış Doktora Tezi. Gazi Üniversitesi, Ankara 2012.

Azevedo R., Cromley J. G., Winters F. I., Moos D. C. \& Greene J. A. (2005). “Adaptive Human scaff olding Facilitates Adolescents' Self-Regulated Learning with Hypermedia". Instructional Science 33 (2005) 381-412.

Bandura A. \& Wood R. (1989). "Effects of Perceived Controll Ability and Performance Standards on Self-Regulation of Complex decision-Making". Journal of Personality and Social Psychology 56/5 (1989) 805-814.

Büyüköztürk Ş. (2011). Sosyal Bilimler Iç̧in Veri Analizi El Kitabı. İstatistik, Araştırma Deseni, Spss Uygulamalarl ve Yorum. Ankara 2011.

Canca D. (2005). Cinsiyete Göre Üniversite Öğrencilerinin Kullandıkları Bilişsel ve Bilişüstü ÖzDüzenleme Stratejileri ile Akademik Başarıları Arasındaki İlişki. Yayımlanmamış Yüksek Lisans Tezi. Yıldız Teknik Üniversitesi, İstanbul 2005.

Gömleksiz N. M. \& Demiralp D. (2012). “Öğretmen Adaylarının Öz-Düzenleyici Öğrenme Becerilerine İlişkin Görüşlerinin Çeşitli Değişkenler Açısından Değerlendirilmesi”. Gaziantep Üniversitesi Sosyal Bilimler Dergisi 11/3 (2012)777-795.

İsrael E. (2007). Öz-Düzenleme Eğitimi, Fen Başarısı ve Öz-Yeterlik. Yayımlanmamış Doktora Tezi. Dokuz Eylül Üniversitesi, İzmir 2007.

Kaplan E. (2014). Beden Ĕ̆itimi ve Spor Öğretmenliği Öğrencilerinde Öz-Düzenleme: Ölçek Uyarlama Çalışması. Yayımlanmamış Yüksek Lisans Tezi. Akdeniz Üniversitesi, Antalya 2014.

Kaya S. (2012). Bilişsel ve Üstbilişsel Strateji Etkinliklerinin Öğretmen Adaylarının Öğretim Tasarımı Dersi Başarllarına, Bilişsel ve Üstbilişsel Stratejileri Kullanma Düzeylerine Etkisi. Doktora Tezi. Ankara 2012.

Kurman J. (2004). "Gender, Selg Enhancement, and Self Regulation of Learningbehaviors in Junior High School". A Journal of Research, Sex Roles 50-9/10 (2004).

Martinez-Pons M. (2000). "Effective Transfer as a Self-Regulatory Process: Implications for Adult Education". Paper Presented at the Royaumont Symposium on Self-Learning, Paris (2000).

Miller J. W. (2000). "Exploring the Source of Self Regulated Learning: The Influence of Internal and External Comparisons". Journal of Instructioanal Psycholohy 2/1 (2000) 1- 34.

Olson T. D. (2009). Assessment of Preservice Physical Education Teacher Education (Pete) Students' Self-Regulation: Implications for Teacher Foundational Enhancement. Unpublished Doctoral Dissertation. The University of New Mexico, Albuquerque 2009.

Ommundsen Y. (2006). "Pupils' Self-Regulation in Physical Education: The Role of Motivational Climates and differential Achievement Goals". European Physical Education, Review 12 (2006) 289.

Pintrich P. \& De Groot A. (1990). "Motivational and Self Regulated Learning components of Classroom Academic Performans". Journal of Educational Psychology 82/1 (1990) 33-40.

Schunk D. H. (2001). "Self-Regulation through Goal Setting". ERIC/CASS Digest ED462671 (2001).

Schuitema J., Peetsma T. \& van der Veen I. (2012). "Self-Regulated Learning and Students' Perceptions of Innovative and Traditional Learning Environments: A Longitudinal Study in Secondary Education". Educational Studies 38/4 (2012) 397-413.

Tanrıseven I. \& Dilmaç B. (2013). “Orta Öğretim Öğrencilerinin İnsani Değerleri, Motivasyonel İnançları 
ve Öz-Düzenleme Stratejileri Arasındaki Yordayıcı İlişkiler”. Kuram ve Uygulamada Ĕgitim Bilimleri, Educational Sciences: Theory \& Practice 13/1 (2013) 21-36.

Toering T., Gemser M. T. E., Jonker L., Heuvelena M. J. G. \& Visscher C. (2012). "Measuring SelfRegulation in a Learning Context: Reliability and Validity of the Self-Regulation of Learning SelfReport Scale (SRL-SRS)". International Journal of Sport and Exercise Psychology 10/1 (March, 2012) 24-38

Uygun M. (2012). Öz-Düzenleme Stratejisi Gelişimi Öğretiminin Yazıl Anlatıma, Yazmaya Yönelik ÖzDüzenleme Becerisine, Kalıcılığa ve Tutuma Etkisi. Yayımlanmamış Doktora Tezi. Hacettepe Üniversitesi, Ankara 2012.

Üredi I. (2005). Algılanan Anne Baba Tutumlarının İlkögretim 8. Sinıf Öğrencilerinin Öz-düzenleyici Öğrenme Stratejileri ve Motivasyonel İnançları Üzerindeki Etkisi. Yayımlanmamış Doktora Tezi. Yıldız Teknik Üniversitesi, İstanbul 2005.

Üredi I. \& Üredi L. (2005). "İlköğretim 8. Sınıf Öğrencilerinin Öz-Düzenleme Stratejileri ve Motivasyonel İnançlarının Matematik Başarısını Yordama Gücü”. Mersin Üniversitesi Eğitim Fakültesi Dergisi 1/2 (Aralık, 2005) 250-260.

Yüksel İ. (2013). “Öğretimsel Stil Tercihlerinin Öz-Düzenleme Beceri Düzeylerini Yordama Gücü”. Dicle Üniversitesi Ziya Gökalp Ĕ̈itim Fakültesi Dergisi 20 (2013) 212-229.

Zimmerman B. J. \& Pons M. M. (1995). "Student Differences in Self Regulated Learning: Relating Grade, Sex, and Giftedness to Self Efficacay and Strategy Use". Journal of Educational Psychology 82 (1995) 51-59.

Zimmerman B. J. (2000). Attainment of Self-Regulation: Asocial Cognitive Perspective. Eds. M. Boekaerts, P. R. Pintrich \& M. Zeidner, Handbook of Self-Regulation (2000) 13-39. San Diego. 